\title{
7 Debating deportation detention in Germany
}

\author{
The many faces of the rule of law
}

Johanna Caroline Günther

\section{Introduction}

Deportation detention ${ }^{1}$ and deportation detention facilities are controversial, yet seldom surfacing topics in German public debate; similarly, research on the politics and policies of deportation detention in Germany is scarce. Deportation detention is an instrument aimed at ensuring the seamless deportation of a person who despite being obliged to leave for their country of origin, a safe third country, or another member state of the European Union, has refused to do so voluntarily (Keßler 2019).

Through an analysis of the portrait of deportation detention as painted by German news media, I map out the values and actors within the debates about, and approaches to, deportation detention in Germany. By studying the contestation of deportation detention, I investigate the value practices and value agents that shape German asylum policy. In this chapter, I set out to answer the following questions: do descriptions of the context in which deportation detention is implemented differ, depending on different groups of actors? Are the values these actors refer to when talking about deportation detention similar or different? Finally, do they understand the same thing when talking about specific values?

Finding answers to these questions not only helps bring to light the influential stakeholders within the debates on and implementation of deportation detention; it also speaks to the larger dynamics regarding the evolution of asylum policy in Germany. Lastly, capturing the values surfacing in this context is essential to understanding the underlying drivers of policy decisions, as well as shifting public perceptions.

I define values, in line with Rokeach's conception, as abstract ideals, positive or negative, which are representative of a person's beliefs about adequate modes, means, and ends of action: 'In brief, then, values may be thought of as global beliefs about desirable end-states underlying attitudinal and behavioral processes' (Rokeach 1979: 72). I conceive of value agents as individuals or collectives, such as non-governmental organizations or governmental institutions, who promote a specific set of values through their statements, actions and proliferated practices. 


\section{2}

J. C. Günther

Not only is the debate on the purpose and practices of deportation detention in Germany representative of partisan political conflicts. It is also closely linked to a value-based divide within Germany society: on one side, individuals and organizations advocating an open, rights-centered approach to migration, on the other actors and groups invoking sentiments of xenophobia and nationalism. Both camps, however, refer to highly value-driven concepts like the rule of law as well as a sense of justice when arguing their positions. This chapter marks an attempt to further split open these arguments and analyze the underlying values.

In Germany, the latest development in a long chain of events in the context of deportation detention is the so-called Geordnete-RückkehrGesetz (Orderly Return Law). It was introduced by the Ministry of the Interior and passed by the German Bundestag in June 2019. The law aims at improving enforcement of deportations of rejected asylum-seekers (Geordnete-Rückkehr-Gesetz 2019). In addition to expanding the instrument of deportation detention the law requires asylum-seekers to remain in first-reception facilities for up to 18 months. The law also stipulates a temporary suspension of the separation of deportation detention and penal detention facilities in order to counter the lack of detention places in deportation detention facilities - 500 places in penal facilities are to be reassigned to deportation detention. The law follows the rationale of the coalition agreement that the German Federal Government concluded in March 2018. The coalition agreement announced that the government was going to facilitate and expand detention for migrants pending expulsion: 'We are going to enhance the practicability of deportation detention and deportation custody; we are going to reduce and clarify the requirements. The goal is to significantly increase the quota of return and deportation measures' (CDU, CSU \& SPD 2018: 107).

Several similarly striking events had preceded this legislation. In September 2016, German Chancellor Angela Merkel was cited in the German media calling for 'deportation, deportation and again, deportation' (Pany 2016) in a non-public meeting of the parliamentary group. This statement marked a rapid departure from the welcoming slogan of summer 2015: 'We can do this.' According to various media outlets, Merkel reinforced her changed narrative during Germany Day (Deutschland Tag) of the Young Union, the joined youth organization of the two conservative German political parties, CDU and CSU, in October 2016 when she said: 'we need a national effort for strict deportation' (Unknown 2016). In July 2017, the German Bundestag passed the first law on 'improved enforcement of the obligation to leave the country' (Gesetz zur besseren Durchsetzung der Ausreisepflicht 2017) amending the provisions on deportation detention set by $\S 62$ of the Residence Act (Aufenthaltsgesetz 2017). In July 2018, the Federal Ministry of the Interior published its much-anticipated 'Migration Masterplan' (Masterplan Migration). Paragraph 59 stresses the importance of deportation detention in order to prevent migrants from 
absconding, and to increase (forced) returns. It specifies that the federal states are to create more places in deportation detention facilities and that further options for the federal government to build its own facilities are to be evaluated (Federal Ministry of the Interior 2018).

Following these political and legislative developments, in the past three years, the German federal states (Länder) have taken steps to expand existing detention facilities, establish a new form of centralized 'reception, decision and return centers' (AnkER Zentren) where asylum-seekers are to remain until the decision is final regarding whether they can stay or must return to their countries of origin or to a safe transit country. According to unofficial statistics, 676 places in deportation detention facilities are currently available. An additional four facilities offering 440 more places are being established. Moreover, 160 more places are to be created within the already existing facilities (Keßler 2019).

Meanwhile, civil society organizations are implementing a campaign against deportation detention: 100 years of deportation detention. 100 years of innocent prisoners (100 Jahre Abschiebehaft. 100 Jahre unschuldig in Haft). The campaign is civil society's most coordinated effort yet to organize at the federal level and harmonize protests, public talks, and events promoting the abolishment of deportation detention (Gockel 2019).

The subsequent sections address selected findings from the analysis of media articles and interviews that help understand which issues, values and actors emerge within the context of deportation detention in Germany. A section on the impact of the European context as addressed in the media articles and highlighted in the interviews concludes the analysis. The discussion of selected topics from the articles and interviews is crucial to understanding the surfacing values within a larger context of shifting public debate, a polarizing political landscape and a diversifying set of influential stakeholders.

\section{Analyzing references to deportation detention - some methodological considerations}

The findings presented in this chapter are based on a qualitative content analysis of German news articles from three media outlets and a randomly selected sample of articles by different news outlets, all of which were published in the period from January 1 to December 10, 2018. This time frame was chosen to ensure that the implications of the key policy shifts outlined above were accounted for, the new government coalition had consolidated its policy priorities and had started executing them, and the revisionary efforts at European level concerning the Common European Asylum System (CEAS) could be integrated. In addition to the analysis of news articles, I conducted interviews with lawyers and representatives of civil society organizations, all of whom promote the rights of deportation detainees. 
Pursuing a predominantly qualitative approach to content analysis (Schreier 2013) - coupled with elements of quantitative media content analysis (Neuendorf 2017) - I identified three relevant media outlets representing a broad spectrum of political positions and audiences: Süddeutsche Zeitung, Spiegel Online, and BILD. The selection of these three media outlets was based on considerations such as political tenor, reach, and coverage. All three media outlets report on local incidents as well as nation-wide news. While Süddeutsche Zeitung and Spiegel Online belong to the left-wing, social-democratic camp of news media, BILD represents a more conservative agenda. To account for other outlets and political leanings, I conducted an online news search for the terms 'Abschiebehaft' and 'Abschiebungshaft' (both: deportation detention) for the same period of time and added the resulting articles to the analysis. ${ }^{2}$ The interviews with representatives of civil society organizations were then used as additional sources of information and to expand on the opinions offered in the media articles.

The quantitative nature of media analysis, as for instance promoted by Neuendorf (2017), allowed me to integrate observations on more structural features such as the thematic category a given article was tagged with, whether the article was written by a journalist from the selected outlet or a news agency, or the frequency of references to certain values: 'Content analysis may be briefly defined as the systematic, objective, quantitative analysis of message characteristics' (Neuendorf 2002: 1). Qualitative content analysis on the other hand comes in as a bridging tool linking the rigorous categorybased approach of quantitative content analysis with interpretative procedures uncovering contextual meaning. Due to their significant difference in levels of objectivity, both methods do not seem reconcilable at first glance. Yet, they inform each other when applied systematically and in separate, consecutive steps.

\section{The 'local hook': deportation detention as a local phenomenon in news articles}

A total of 139 articles - divided into four groups - constituted the body of analysis: Süddeutsche Zeitung contributed 46 articles. Spiegel Online provided 17 articles. BILD published 24 articles within the analyzed period. The additional sample, which encompassed a ratio of approximately two thirds conservative or populist and one third left-liberal to socialist media outlets accounted for 52 articles. For all three selected media outlets a peak of articles addressing deportation detention can be observed in May, with a total of 27 articles featuring the topic 'deportation detention' either as a main or as a side topic. In June and July, 17 and 18 articles, respectively, were published by the selected media outlets, making these three months the period with the densest coverage of deportation detention. Two key events can be held responsible for this observation: the election campaigns in Bavaria which featured asylum and deportation among the central topics, and a 
violent incident at a migrant reception center in Ellwangen, Baden-Wurttemberg, which occurred during a deportation attempt. In February 2018, issues related to deportation detention received the least attention with only five articles published.

When analyzing the tags the editors chose for the individual articles, the picture is very diverse: assigned tags vary from 'Legislative proposals,' 'Bavaria's prime minister,' and 'Rule of law' via 'Islamist.' 'Reception facility for asylum-seekers,' 'Protests in Ellwangen' and 'Germany's biggest deportation detention facility' to 'Government statement,' 'Deportation debate' and 'Munich airport.' ${ }^{3}$ It is however striking that all outlets report on issues related to deportation detention predominantly from a local angle, using city names as tags rather than thematic categories like 'Deportations' or 'Asylumseekers.' In total, 36 articles are tagged with a city name. Spiegel Online deviates from this pattern and more frequently assigns thematic categories instead of geographical ones. In terms of thematic categories, 'Politics' (27) and 'Regional' (36) are the ones assigned most often.

\section{The politicization of deportation detention - a representation of partisan political struggles}

The entirety of articles produced 24 topics shaping the context of debates on deportation detention. References to legislation and legal procedures regarding deportation detention were the most frequently occurring theme in the media sample (173). Then followed mentions of policies related to deportation detention and political conflicts regarding the set-up, requirements, and desirability of deportation detention as a tool to enforce returns (116). The third theme emerging from the articles was background information, for instance listing the nationalities of detained migrants, the number of detention places, or the historical development of deportation detention in Germany (113). In a nutshell, most articles focused on, or at least mentioned, either legislative changes or concrete legislative proceedings, policy proposals or political controversies surrounding policies, and information on deportations, deportation detention and detention facilities in a more abstract fashion.

It should be noted that even where media reported on specific cases or incidents involving a detained migrant, there were almost no mentions of the migrants' or detainees' perspectives. Only one article explicitly reported migrants' views on an incident that had led to the transfer of three persons into deportation detention. Another report portrayed the stories of deportation detainees in the detention facility in Büren as told by the concerned individuals. The lack of perspectives of migrants and detainees was corroborated by interviewees who clarified that the limited access for non-governmental organizations, media and legal aid practitioners combined with the fact that 'detainees don't have a lobby' and deportation detention facilities were 'operated like black boxes' resulted in the negligence 
of detainees' voices. Instead, individual cases of detainees were overwhelmingly addressed in the context of either newly emerging legislation and legal steps which must be complied with when detaining a migrant (34), or in relation to acts of violence and crime committed by detainees or guards (33). The third topic arising in regard to individual cases of detainees relates to the latter category: the articles focusing on specific cases or incidents also referred to individuals posing a threat to public security (18). Hence, they reiterated the perception that deportation detention provided an essential tool to combat serious crimes. On one hand, these observations could hint towards the limitations of the media's interest in the processes and events occurring inside deportation detention facilities. On the other, limited coverage of incidents inside detention facilities as well as detainees' perspectives may also be a result of restricted access for journalists and civil society organizations to detention facilities.

There are two main representations of the theme of 'legislation and legal procedures' when it comes to describing incidents involving deportation detainees: either the article refers to the case of an individual that was taken to court or had undergone the process of applying for asylum, or policymakers gave individual cases of criminal asylum-seekers as reasons for the need to come up with more restrictive laws, including expanding deportation detention. In other words, either the article featured a technical description of the legal procedures related to deportation detention and asylum applications, or it viewed legislation on deportation detention through a political lens, i.e. as a solution reducing crime.

The combination of the portrayal of individual cases of detainees in relation to the topics of violence and crime brings about a multi-faceted picture. Even though most texts refer to cases that involve an asylum-seeker who has committed a crime or misdemeanor, there are also reports on prison guards and prison managers who allegedly abused detainees. An illustrative example for the link between cases and crime as most frequently portrayed in the analyzed articles is an assessment presented by Berliner Zeitung:

Ilyas A. had been in jail. He had not been transferred to deportation detention after he had finished his jail time. This was for a very simple reason: the governing Red-Red-Green Senate wanted to abolish deportation detention. In October 2016, the Social Democrats, the Left Party and the Greens agreed that deportation detention was an 'inadequate measure' and should not be applied any longer. This is why Ilyas A. was released and this is also why Mahmut A. was released from prison. If both had been deported, Susanne Fontaine had not been strangled and Than N. had not been stabbed to death.

(Schupelius 2018)

Another example is Neue Westfälische's article on more restrictive practices inside the detention facility in Büren, North Rhine-Westphalia, as a 
consequence of terrorist threats and a rising number of convicted asylumseekers awaiting deportation:

Prosecutors' offices and Immigration Authorities now inform more systematically about so-called 'threats to public security' [Gefährder]. If possible, refugees with a criminal past do not remain at large any longer but are moved to the only deportation detention facility in Büren.

(Finke 2018)

Interviewees shed more light on this finding. All of the interviewed representatives of civil society organizations emphasized that it is crucial to understand that deportation detention is not ordered because a migrant has necessarily committed a crime. Legally, deportation detention is treated solely as means to an end to enforce the measure itself: deportation. However, several interviewees mentioned that this important differentiation was neither well known among the public nor among the media. According to interviewees, journalists and politicians often reinforced the wrong assumption that migrants held in deportation detention facilities were also criminals.

An example showing a different representation of an incident inside a deportation detention facility that involved violence and crime is an article published by Neues Deutschland, a newspaper with socialist leanings. It covers a court case involving prison guards who had allegedly abused and injured detainees:

A man was forced to lay down on a mattress full of sick while being threatened; moreover, photos of torture scenes. The prosecutor's office accuses the 30 defendants, mostly security guards, of several crimes such as bodily injury, coercion, theft and deprivation of liberty in 54 cases.

(Weiermann 2018)

A closer look at the policies and political struggles addressed in the articles reveals a wide range of topics: new legislative initiatives, the expansion of deportation detention facilities, background information on deportation detention, as well as fundamental rights concerns are raised in the context of policy and politics related to deportation detention in Germany. References to legislation and legal procedures as well as information on the number of detainees held in deportation detention can to some extent be expected since policies often result in, or are accompanied by, legislative efforts and are corroborated by statistics and contextual information. However, the other two thematic categories are less obvious, and yet all the more telling. When it comes to expanding the capacities of deportation detention facilities, articles predominantly refer to state level efforts in Saxony, Schleswig-Holstein, Bavaria and North Rhine-Westphalia to create new deportation detention facilities as well as the political debates emerging around these plans. 
Remarkably, news articles do not discuss any national efforts to expand deportation facilities. Even though deportation detention is a competence of the states, the national trend towards more detention places as laid out in the 'Migration Masterplan' is only highlighted by one article. In the context of Bavaria, deportation detention constituted a hot topic during the state elections. In those articles referring to Bavarian election campaigns, references to plans related to the expansion of deportation detention facilities often contain quotes of politicians promising more detention places, and greater efforts to enforce deportations.

When focusing on the concerns of fundamental rights brought up in the articles, a diverse picture emerges: on one hand, human rights concerns come up in the context of political exchanges in state parliaments over more restrictive deportation detention policies. On the other, we find expert assessments of current deportation detention policies and practices. Beyond this, news articles cite civil society organizations which criticize legislative proposals or the enforcement of legislation in light of fundamental rights concerns. Following up on these critiques, the interviewed representatives of civil society organizations reiterate their concerns that when it comes to deportation detention orders, public agencies do not live up to their obligations as representatives of the constitutional state. On the contrary, all interviewees raise concerns as to the low quality of the decisions regarding procedural requirements and respect for asylum-seekers' rights.

As for political debate, the following quote from an article of Kieler Nachrichten referring to a much-addressed legislative proposal put forward by the government coalition in Schleswig-Holstein, appears in several other news reports:

The oppositional SPD [Social Democrats] strongly criticized the planned facility as well as the changed legislative proposal. Schleswig-Holstein had successfully enforced deportations without a deportation detention facility, in a way that 'the principles of humanity and human dignity could be ensured,' said the speaker of the faction in matters concerning refugees, Serpil Midyatli. The coalition of CDU, Greens and FDP [Free Democrats] was evidently ready to 'sacrifice essential aspects of the humane refugee policy of the state'.

(Unknown 2018a)

The example below highlights a different manifestation of fundamental rights concerns in relation to policy. Here, a lawyer explains the legal implications of the way deportation detention is set in national and state laws:

The provisions for deportation detention are generally so broad that you could detain someone just because he illegally entered Germany. If there's another additional ground, this would quickly become proportional, then he would be put into deportation detention. Bavaria is 
currently a prime example that the provisions for deportation detention are interpreted in an extremely broad way, and that public authorities and courts judge extremely leniently on those applications.

(Barenberg 2018)

\section{The value dimension: the many faces of the rule of law}

The search for values in the reviewed articles resulted in the identification of six overarching value categories which I then assigned 26 values emerging from and repeated in the articles (see Table 7.1). 'Values' - as referred to in my analysis of articles addressing deportation detention - encompass a) all explicit references to values in the context of deportations and deportation detention and asylum-seekers, and b) all ideas on what deportation detention as well as the policies hereof should look like, and how these ideas should be achieved. The overarching categories as derived from the articles are: Political interests, Respect for (fundamental) rights, Democratic principles, Effectiveness and efficiency of deportation detention, Solidarity with asylumseekers/detainees and Moral claims.

Out of the six categories of 'Values,' 'Democratic principles' (126) is the one that appears the most in the articles, followed by 'Respect for (fundamental) rights' (116). Among the values referred to, 'Rule of law' from the 'Democratic principles' category is raised by far the most often, followed by 'Combatting crime' from the 'Political interests' category (36).

Across all articles, references to the rule of law most frequently appear in conjunction with claims regarding the need to uphold a strong, resilient state on one hand, and on the other in the context of the right to an effective remedy for asylum-seekers to appeal their deportation decision and to prove their eligibility for asylum. But the rule of law also comes up in the context of the right to freedom or in relation to the notion that deportation detention is an inadequate or unjustified measure. An example from Berliner Zeitung which brings up the shift in policy, criticizes that deportation detention had once been on the verge of abolition:

In October 2016, the SPD, the Left Party and the Greens agreed per contract that deportation detention was an 'inadequate measure' and should not be enforced any longer.

(Schupelius 2018)

The rule of law is also a reoccurring motif in the interviews. Interviewees from civil society organizations and lawyers stress that rule of law and the constitutional state are at stake where state agencies and courts treat asylumseekers without adequate considerations for due process and without respecting their rights. Criticizing the high number of flawed deportation decisions overturned by higher courts, interviewed stakeholders advocating for the rights of migrants in deportation detention refer to their motivation 


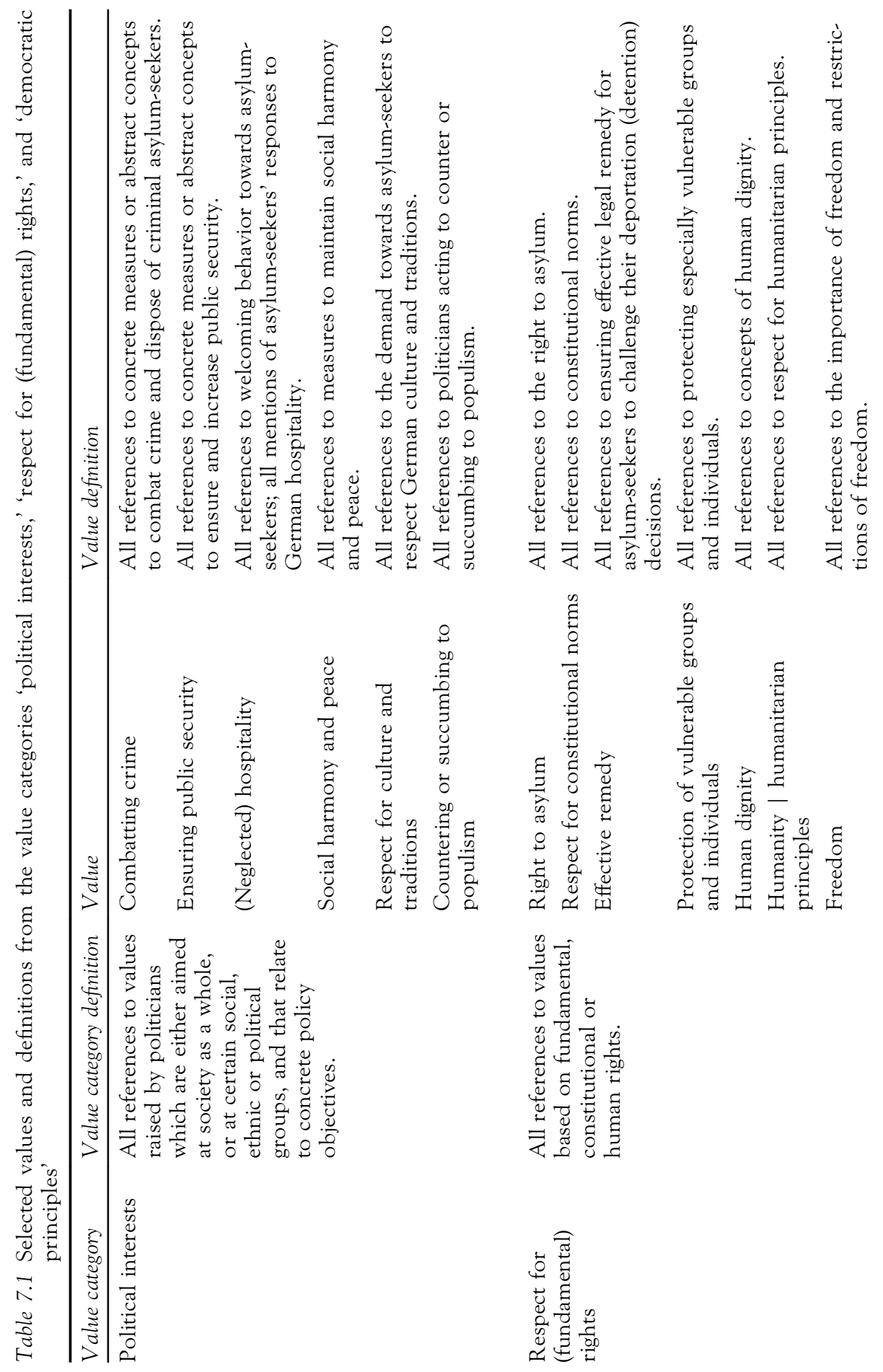



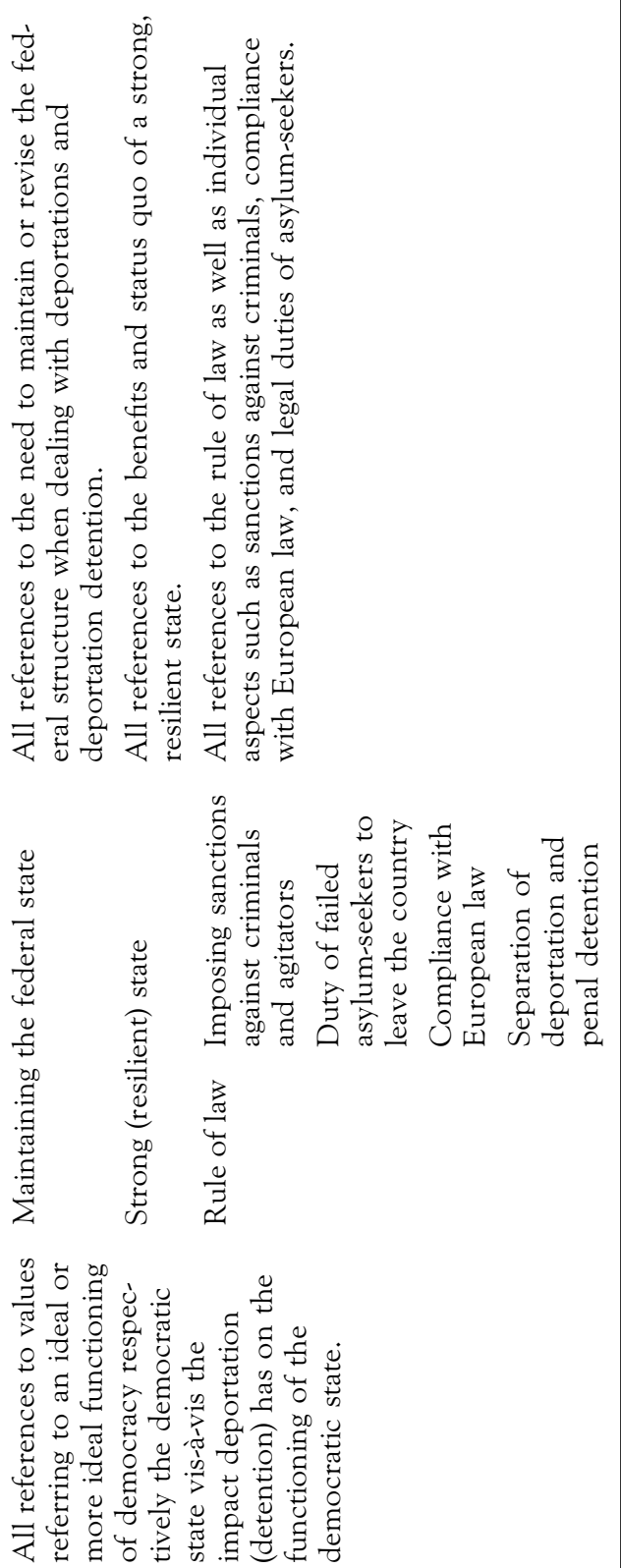

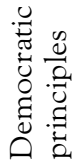


as the desire to uphold justice, and to ensure that detained migrants' voices are heard, and their rights respected. ${ }^{4}$

In almost all cases where an article referred to the duty of refused asylumseekers to leave the country, the author cited a politician arguing that the need to establish more restrictive policies aimed at better enforcement of the rule of law arose as a result of asylum-seekers not leaving voluntarily after their application had been rejected. Moreover, notions of the duty of failed asylum-seekers to leave the country often appeared in conjunction with references to the need for Germany to appear as a strong, resilient state committed to its constitutional values. The subsequent example from Fehmarn24, a North German news portal, illustrates this link:

Speaking for the FDP the speaker of the faction in matters concerning domestic policy, Jan Marcus Rossa, said that creating deportation detention facilities was not a political goal of his party. 'Unfortunately, we are forced to do so if we want to enforce our constitutional state.' It would be better if persons obligated to leave the country left Germany voluntarily.

(Unknown 2018b)

Several articles also cite politicians who spoke of a group of convicted refused asylum-seekers to underline their point that the state needed to act more strongly in enforcing deportations to maintain public order and the rule of law. It should be noted that the majority of the articles addressing this nexus comes from the months May and June when a tumultuous incident in the Ellwanger reception facility for asylum-seekers had occurred, and several acts of violence were reported from the deportation detention facility in Büren. This example from Fürther Nachrichten in Bavaria illustrates the link between convicted asylum-seekers, enforcing the rule of law and upholding the image of a strong, resilient state:

[Mayor] Jung pressed for eliminating this 'gap in law', among others in a letter to SPD party leader Andrea Nahles. It couldn't be that criminals who were obliged to leave the country could force their stay. The state's options to sanction were too weak. In the case of lacking cooperation, deportation detention had to be made available more quickly.... A constitutional state, said the mayor, had to be measured against its power to enforce the law.

(Unknown 2018c)

Where the rule of law was brought up in conjunction with the assessment that deportation detention was an inadequate measure, most articles cited politicians criticizing deportation detention on the basis of flawed legal procedures. 
Jelpke criticized the ignorance in this area [cases of unlawful deportation detention]: It was telling that unlawful deportation detention was not systematically recorded. 'Who doesn't record their own mistakes, doesn't have to deal with those mistakes,' said the politician. 'Evidently, refugees' rights to freedom mean so little to German authorities that they readily accept their unlawful detention - if that serves the better enforcement of deportations.'

(Kastner 2018)

\section{A great cluster of values, a small consortium of value agents}

The examples above highlight one key finding: as portrayed by the media, politicians represent one main group of value agents - if not the most dominant one - in the context of deportation detention in Germany, irrespective of whether they are for or against it. Even though this group is very diverse in its positions depending on their political affiliation and whether they are part of the government (coalition) or of the opposition, the analyzed articles reveal similarities in the values politicians refer to. The second influential group is also fairly heterogenous and consists of civil society organizations such as the Jesuit Refugee Service, various Refugee Councils and locally active non-governmental organizations like 'Help for People in the Deportation Detention Center Büren' (Hilfe für Menschen in Abschiebehaft Büren). Other important value agents as portrayed by the media are official monitoring institutions, such as the National Agency for the Prevention of Torture, as well as lawyers and law firms.

Table 7.2 Value agents shaping the debate about deportation detention

\begin{tabular}{|c|c|c|c|}
\hline $\begin{array}{l}\text { Main } \\
\text { Category }\end{array}$ & Definition & Sub-Category & Definition \\
\hline \multirow[t]{4}{*}{ Value Agents } & \multirow{4}{*}{$\begin{array}{l}\text { All mentions of } \\
\text { individuals and/ } \\
\text { or organizations } \\
\text { and/or institu- } \\
\text { tions active and } \\
\text { influential in the } \\
\text { context of depor- } \\
\text { tation detention } \\
\text { which promote } \\
\text { specific (sets of) } \\
\text { values. }\end{array}$} & $\begin{array}{l}\text { Civil Society } \\
\text { Organizations }\end{array}$ & $\begin{array}{l}\text { All references to actors from } \\
\text { non-governmental, civil society } \\
\text { organizations. }\end{array}$ \\
\hline & & Politicians & $\begin{array}{l}\text { All references to policymakers } \\
\text { from federal, state and local } \\
\text { levels. }\end{array}$ \\
\hline & & $\begin{array}{l}\text { Monitoring } \\
\text { institutions }\end{array}$ & $\begin{array}{l}\text { All references to public institu- } \\
\text { tions in charge of monitoring } \\
\text { human rights compliance, } \\
\text { including courts. }\end{array}$ \\
\hline & & $\begin{array}{l}\text { Lawyers | } \\
\text { Law firms }\end{array}$ & $\begin{array}{l}\text { All references to legal profes- } \\
\text { sionals and law firms promot- } \\
\text { ing and defending the rights of } \\
\text { deportation detainees. }\end{array}$ \\
\hline
\end{tabular}


The three values the different groups of value agents refer to the most are: upholding the rule of law (57), the need to combat crime (28) and complying with humanitarian principles (22). It is however worth exploring less frequently addressed categories such as the appeal to solidarity with asylumseekers (14), the appeal to protecting vulnerable groups and individuals (12) and the notion of countering or succumbing to populism (7).

A closer look at the text sections coming up when looking at value agents discussing how to combat crime in the context of asylum-seekers, reveals that in most cases, politicians or police officials tie these two topics together. Where civil society organizations appear, it is mostly to urge caution when using convicted asylum-seekers as a reason for more restrictive deportation (detention) policies. Interestingly, civil society organizations - and the same holds true for lawyers, law firms and monitoring institutions - exclusively feature as opponents of politicians or facility staff and police demanding an expansion of deportation detention facilities, or critics of legislative proposals allowing for a more liberal use of the instrument of deportation detention.

None of the articles features non-governmental organizations which support the instrument of deportation detention. Interviewees from civil society organizations shed light on this observation: they state that NGOs active in this thematic area are scarce and often barely connected. Moreover, attempts to build a national network are still in the early stages. According to interviewees, civil society usually organizes around a local detention facility aiming to help the detainees inside. Hence, when consulted for news articles, NGOs predominantly featured as a balancing voice contrasting politicians' views on the benefits of expanding deportation detention. Interviewees partly reiterated this view during the interviews: The majority of interviewed stakeholders stressed that while they generally advocated for an abolition of deportation detention, their main concern was that where there had been a detention order the decision complied with all legal, procedural standards and respected the rights the constitutional state had given to every individual. As one interviewee put it:

The people who are pro deportation detention keep saying that we must preserve the rule of law; but they always refer to the constitutional state as the state that must enforce the law against the weaker members of society. However, rule of law also means that we must protect the weakest; and that doesn't happen. We established rules and now we don't play the game according to them.

Arguments linking value-based statements on combatting crime to asylumseekers are usually raised by politicians and based on references to specific cases of migrants who committed a crime. Here, again, the lack in differentiation between the purpose of deportation detention and criminal punishment is manifested. The following value-based statements - one from an article in Frankfurter Rundschau and the other from an article of BILD - are examples of how refused asylum-seekers, crime, and deportation detention 
are interlinked by politicians and public authorities as portrayed in the analyzed articles:

The South-Hesse police president Bernhard Lammel, whose department is in charge of the new deportation detention facility in Darmstadt, has recently made a different impression. He told the local press: 'The focus is on those who don't comply with our law.' It couldn't be conveyed to citizens that people who commit crimes are permitted to stay.

(Bebenburg 2018)

[The Berliner] CDU-faction leader Burkard Dregger (54) raises concerns. He points to individual felons among the asylum-seekers: 'They are dangerous. A person like the Tiergarten-murderer of Susanne F. should have been in deportation detention after committing that crime.

(Unknown 2018d)

Finally, the group of politicians demands further differentiation. Generally, the Left Party, the Greens and in some cases the SPD are portrayed as fierce critics of the concept and the instrument of deportation detention. Yet, where the Greens are part of the government (coalition) like in Schleswig-Holstein or Baden-Wurttemberg, representatives of the party appear less morally condemning in the articles. Instead, they stress the need to increase the number of persons returning to their countries of origin and describe deportation detention as a necessary means to that end. Furthermore, the vast majority of statements cited from Bavarian politicians vehemently advocate for more places in deportation detention facilities and a more liberal use of the instrument of deportation detention. While this is an important finding, it must be noted that the sampled articles are from a period of time that overlaps with the Bavarian state election, which included immigration and asylum-seekers as key topics.

An assessment repeated throughout the interviews helps grasp the context of the debate on deportation detention in Germany: positions on deportation detention have increasingly become a yardstick clarifying a politician's leaning within the overarching debate on the future of German asylum policy. Deportation and deportation detention have, therefore, become the prism breaking up a wide range of political interests and goals, reaching from regulatory and security-related considerations, preserving social welfare, combatting crime and living up to international obligations to the promotion of human rights.

\section{The invisible European dimension}

The ongoing revision processes concerning the Common European Asylum System (CEAS) and more specifically, the Dublin III Regulation and the 
Return Directive, promise to amend the list of potential grounds for deportation detention and generally appear to follow a considerably more restrictive approach. The European Commission, in the memorandum of the latest draft of the Return Directive, announced that the proposal aimed to 'ensure a more effective use of detention to support the enforcement of returns' (European Commission 2018: 3). The Commission furthermore explained that 'there is need for targeted changes in the rules on detention. Firstly, new risks have emerged in recent years, which make it necessary that illegally staying third country nationals who pose a threat to public order or national security can be detained if deemed necessary' (European Commission 2018: 8).

In the sampled articles, the European context (16) is not frequently brought up. When it is, it always appears in the form of references to European law or case-law of the Court of Justice of the European Union (CJEU) or the European Court of Human Rights (ECtHR). Most often, articles refer to a judgment of the CJEU prohibiting the joint detention of convicted felons and migrants awaiting deportation. The following example stems from an article of Berliner Morgenpost:

Three years ago, the former deportation detention facility in BerlinGrünau had been closed. So-called 'Gefährder' [person posing a threat] had been temporarily detained in a part of the jail in Tegel prior to their deportation. But the EU stipulates that deportation detainees must be detained in a separate facility, kept away from criminals, as the Senate administration said on Friday.

(Unknown 2018e)

None of the articles discusses the legislative proposals on revising the major European instruments to regulate deportation detention: the Dublin III Regulation and the Return Directive. This is starkly contrasted by the results from the interviews: all representatives of civil society organizations stress the importance of these legislative processes for the practice of deportation detention in Germany and raise concerns that the current drafts will result in a more liberal use of deportation detention.

\section{Conclusion}

The analysis of 139 articles, as well as complementary expert interviews, aimed to shed light on the question of which values dominated public discourse regarding deportation detention, and which value agents were promoting them. Six groups of values containing a total of 26 sub-category values were identified, of which 'Democratic principles' and 'Respect for (fundamental) rights' are the value categories most frequently referred to. The way value agents raised these values, however, differed considerably. While in the analyzed articles politicians would bring up the 'Rule of law' mostly to argue that deportation detention was necessary to ensure the 
functioning of the constitutional state, civil society organizations referred to the 'Rule of law' when criticizing unlawful deportation detention.

When specifically examining value agents and the values they brought up, a strong divide among groups of value agents becomes apparent. While references to exercising solidarity with asylum-seekers are barely found among politicians; lawyers and civil society organizations dominate this value category. The picture changes when exploring the references to the need to combat crime or ensure public safety, which are defined by politicians' statements.

Generally, it is remarkable how frequently deportation detention is discussed in regard to specific cases of detainees, rather than at a more abstract policy level. In this context, it is even more noteworthy that the voices of (former) deportation detainees are almost never featured in the analyzed articles. Experts from civil society offer two explanations for this finding: on one hand, access to deportation and reception facilities is extremely limited. On the other, public awareness of the specific legal requirements of deportation detention - migrants in deportation detention do not need to have committed a crime - is very limited and therefore, there is no broad interest to listen to deportation detainees' side of the story. In fact, all interviewees stressed how small a community the circle of experts on deportation detention is.

Lastly, even though neglected in media articles, according to interviewees the European level strongly affects national policies on deportation detention which otherwise is a competence of the German federal states. Governance structures are therefore complex with a multitude of stakeholders involved. Experts expect the currently ongoing revision of the Dublin Regulation as well as the Return Directive to have considerable impact on the German practice of deportation detention; likely, pushing it towards a more restrictive approach.

The complexity of this policy area is mirrored by the different sets of values raised in the context of deportation detention. While the majority of identified values broadly refers to structures of the state or society, only one set of values (solidarity with asylum-seekers and detainees) addresses detained migrants directly. Furthermore, divergent interpretations of the same values, for instance upholding the rule of law, complicate communication efforts between the different groups of value agents who seem to hold value-based, and therefore hardly negotiable, positions.

The trend towards a more restrictive asylum policy in Germany goes hand in hand with an expansion of legal grounds for ordering deportation detention, as well as the establishment of further detention facilities. The overview of values surfacing as part of the debate on deportation detention has foregrounded the fact that values in the context of deportation detention seem to be closely tied to an idea of a troubled constitutional state that must find its way back to and show its strength by strictly enforcing the rule of law, and thus deportations; or otherwise, risk unsettling societal peace and compromising public security. This development speaks to the overarching shifts in 
the socio-political climate in Germany: from the country of 'refugees welcome' to a highly polarized nation fearful that more migration will lead to an ever-greater divide in society. ${ }^{5}$

\section{Notes}

1 Across different literatures, the German term "Abschiebungshaft" has also been translated as immigration detention, migrant detention, pre-expulsion detention, removal detention, and detention pending removal. However, in order to attempt a literal translation that also demarcates the concept as clearly as possible I use the term "deportation detention".

2 For more on the sampling process, see for instance Newbold et al. (2002: 63 and 80 f.), Macnamara (2005: 3; 13 and 18); Patton (2002: 230 ff.) or Krippendorff (2004: $111 \mathrm{ff}$.

3 'Bavaria's prime minister': a category emerging as a consequence of the Bavarian state election that featured asylum-seekers and related subjects as key topics.

'Protests in Ellwangen': The reception centre for asylum-seekers in Ellwangen made headlines because of a violent incident between the police and residents of the centre.

'Munich airport': This tag showed up in relation to the new detention facility at Munich airport.

4 According to the Federal Office for Migration and Refugees, in 2018, 17.1 percent of all court decisions where issued in favor of the complainants. In 2017, this number had been 22 percent (Federal Office for Migration and Refugees 2019).

5 See for instance the Friedrich Ebert Foundation's (2019) survey on Germans' perceptions of migration.

\section{References}

Barenberg, J. (2018). 'Forderung nach Gesetzesverschärfung ist "Schaufensterpolitik",' Deutschlandfunk, 5 May 2018. Available at: www.deutschlandfunk. de/anwalt-zu-abschiebehaft-forderung-nach.694.de.html?dram:article_id=417257

Bebenburg, P. (2018). 'Straffälligkeit spielt für Abschiebehaft keine Rolle,' Frankfurter Rundschau, 26 June. Available at: www.fr.de/rhein-main/die-linke-org26318/straffa elligkeit-spielt-abschiebehaft-keine-rolle-10986963.html

CDU, CSU \& SPD (2018). Ein neuer Aufbruch für Europa. Eine neue Dynamik für Deutschland. Ein neuer Zusammenhalt für unser Land, 6 March. Available at: www. cdu.de/system/tdf/media/dokumente/koalitionsvertrag_2018.pdf?file=1

Directive of the European Parliament and of the Council on common standards and procedures in Member States for returning illegally staying third-country nationals (recast) (COM(2018) 634 final) (2018). Official Journal of the European Union.

Entwurf eines Zweiten Gesetzes zur besseren Durchsetzung der Ausreisepflicht (2019). (Geordnete-Rückkehr-Gesetz), German Federal Government, Berlin.

European Commission (2018). Proposal for a DIRECTIVE OF THE EUROPEAN PARLIAMENT AND OF THE COUNCIL on common standards and procedures in Member States for returning illegally staying third-country nationals (recast), 12 September. Available at: https:/ec.europa.eu/commission/sites/beta-political/files/soteu2018-r eturning-illegally-staying-third-country-nationals-directive-634_en.pdf

Federal Ministry of the Interior (2018). Masterplan Migration. Bundesministerium des Innern, 4 July. Available at: www.bmi.bund.de/SharedDocs/topthemen/DE/top thema-masterplan-migration/topthema-masterplan-migration.html 
Federal Office for Migration and Refugees (2019). Gerichtsstatistik 2018, BAMF, 28 March. Available at: www.bamf.de/SharedDocs/Meldungen/DE/2019/20190328-ger ichtsstatistik-2018.html?nn=1367522

Finke, K. (2018). 'Bedingungen in Bürener Abschiebehaftanstalt werden verschärft,' Neue Westfälische, 3 October. Available at: www.nw.de/lokal/kreis_paderborn/bueren/ 22259912_Bedingungen-in-Buerener-Abschiebehaftanstalt-werden-verschaerft.html

Friedrich Ebert Foundation (2019). Umfrage: Was die Deutschen über Migration denken. FES, 19 March. Available at: www.fes.de/themenportal-flucht-migration-integra tion/umfrage-was-die-deutschen-ueber-migration-denken

Gesetz über den Aufenthalt, die Erwerbstätigkeit und die Integration von Ausländern im Bundesgebiet (2017). (Aufenthaltsgesetz - AufenthG), Bundesgesetzblatt, Bonn.

Gesetz zur besseren Durchsetzung der Ausreisepflicht (2017). Bundesgesetzblatt, Bonn.

Gockel, F. (2019). 100 Jahre Abschiebehaft. Available at: http://100-jahre-abschiebehaft. de/de/startseite

Judgments in Joined Cases C-473/13 and C-514/13 and in Case C-474/13 Adala Bero v Regierungspräsidium Kassel, Ettayebi Bouzalmate v Kreisverwaltung Kleve and Thi Ly Pham $v$ Stadt Schweinfurt (2014), Court of Justice of the European Union, Luxembourg.

Kastner, B. (2018). 'Einsperren, rauswerfen,' Süddeutsche Zeitung, 22 November 2019. Available at: www.sueddeutsche.de/politik/asyl-einsperren-rauswerfen-1.4222389

Keßler, S. (2019). 'Abschiebungshaft,' Socialnet Lexikon, 14 January. Available at: www.socialnet.de/lexikon/Abschiebungshaft

Krippendorff, K. (2004). Content Analysis. An Introduction to its Methodology. Thousand Oaks, CA: SAGE Publications.

Macnamara, J. (2005). 'Media content analysis: Its uses; benefits and best practice methodology,' Asia Pacific Public Relations Journal 6(1), pp. 1-34.

Neuendorf, K. A. (2002). The Content Analysis Guidebook. Thousand Oaks, CA: SAGE Publications.

Neuendorf, K. A. (2017). The Content Analysis Guidebook, 2nd edn. Thousand Oaks, CA: SAGE Publications.

Newbold, C., Boyd-Barrett, O., \& van den Bulck, H. (2002). The Media Book. London: Arnold.

Pany, T. (2016). Merkel: Rückführung, Rückführung und nochmals Rückführung. Heise, 1 September. Available at: www.heise.de/tp/features/Merkel-Rueckfuehrung-Rueckfu ehrung-und-nochmals-Rueckfuehrung-3312398.html

Patton, M. Q. (2002). Qualitative Research and Evaluation Methods, 3rd edn. Thousand Oaks, CA: SAGE Publications.

Unknown (2016). 'Merkel für konsequentere Abschiebungen,' Zeit, 15 October. Available at: www.zeit.de/politik/deutschland/2016-10/angela-merkel-rede-deutschla ndtag-der-jungen-union-paderborn-asylbewerber

Unknown (2018a). 'Kabinett billigt Gesetzentwurf,' Kieler Nachrichten, 11 September. Available at: www.kn-online.de/Nachrichten/Politik/Kiel-Kabinett-billigt-Ge setzentwurf-ueber-den-Vollzug-der-Abschiebungshaft

Unknown (2018b). 'Neues Gesetz für Abschiebehaft,' Fehmarn24, 22 May. Available at: www.fehmarn24.de/schleswig-holstein/innenministerstellt-entwurf-einrichtung-glueckstadt-9890352.html

Unknown (2018c). 'Abschiebehaft: Fürths OB Jung fordert Hilfe von Nahles,' Fürther Nachrichten, 21 November. Available at: www.nordbayern.de/region/abschiebeha $\mathrm{ft}$-furths-ob-jung-fordert-hilfe-von-nahles-1.8327413 
Unknown (2018d). 'Warum schiebt Berlin so wenig ab?' Bild, 7 November. Available at: www.bild.de/regional/berlin/berlin-aktuell/abgelehnt-und-doch-noch-da-warum -schiebt-berlin-so-wenig-ab-58270634.bild.html

Unknown (2018e). 'Neues Abschiebegefängnis für Kriminelle und Gefährder,' Berliner Morgenpost, 21 September. Available at: www.morgenpost.de/berlin/article215384143/ Neues-Abschiebegefaengnis-fuer-Kriminelle-und-Gefaehrder.html

Rokeach, M. (1979). Understanding Human Values. Individual and Societal. London: Collier Macmillan Publishers.

Schreier, M. (2013). 'Qualitative content analysis,' in Flick, U. (ed.) The SAGE Handbook of Qualitative Data Analysis. Thousand Oaks, CA: SAGE Publishing, pp. $170-183$.

Schupelius, G. (2018). 'Späti-Mörder nicht abgeschoben. Justizsenator verweigert Auskunft!' Berliner Zeitung, 12 January. Available at: www.bz-berlin.de/berlin/ kolumne/spaeti-moerder-nicht-abgeschoben-justizsenator-verweigert-auskunft.

Weiermann, S. (2018). 'Demütigungen, Schläge und Gefangenschaft,' Neues Deutschland, 8 November. Available at: www.neues-deutschland.de/artikel/1105283.gewa lt-gegen-gefluechtete-demuetigungen-schlaege-und-gefangenschaft.html. 